\title{
Are Essay Mills committing fraud? An analysis of their behaviours vs the 2006 Fraud Act (UK)
}

\author{
Michael J. Draper ${ }^{1}$, Victoria Ibezim ${ }^{1}$ and Philip M. Newton ${ }^{2 *}$
}

\author{
* Correspondence: \\ p.newton@swansea.ac.uk \\ ${ }^{2}$ Swansea University Medical School, \\ Swansea University, Swansea SA2 \\ 8PP, UK \\ Full list of author information is \\ available at the end of the article
}

\begin{abstract}
Many strategies have been proposed to address the use of Essay Mills and other 'contract cheating' services by students. These services generally offer bespoke custom-written essays or other assignments to students in exchange for a fee. There have been calls for the use of legal approaches to tackle the problem. Here we determine whether the UK Fraud Act (2006) might be used to tackle some of the activities of companies providing these services in the UK, by comparing their common practises, and their Terms and Conditions, with the Act. We found that all the sites examined have disclaimers regarding the use of their products but there are some obvious contradictions in the activities of the sites which undermine these disclaimers, for example all sites offer plagiarism-free guarantees for the work and at least eight have advertising which appears to contradict their terms and conditions. We identify possible areas in which the Act could be used to pursue a legal case but overall conclude that such an approach is unlikely to be effective. We call for a new offence to be created in UK law which specifically targets the undesirable behaviours of these companies in the UK, although the principles could be applied elsewhere. We also highlight other UK legal approaches that may be more successful.
\end{abstract}

Keywords: contract cheating, plagiarism, fraud essay mill, Fraud Act, QAA

\section{Introduction}

The use of so-called 'contract cheating' services by students has been a source of controversy and debate within Higher Education, particularly in the last decade. 'Contract cheating' refers, basically, to the outsourcing of assessments by students, to third parties who complete work on their behalf in return for a fee or some other benefit (Lancaster and Clarke 2016). These services offer 'custom assignments' of almost any form, although custom written essays appear to be the most common. Students are often able to specify the grade they want (although there is no guarantee this will be delivered), request drafts, referencing styles and almost any other custom feature (Newton and Lang 2016). Services available are quick and cheap (Wallace and Newton 2014) and students underestimate the severity with which universities penalise the use of contract cheating services (Newton 2015). Perhaps the simplest arrangements are directly between students and 'custom essay writing companies', many of whom are 'listed' companies with sophisticated advertising campaigns. However there are many

(c) The Author(s). 2017 Open Access This article is distributed under the terms of the Creative Commons Attribution 4.0 International License (http://creativecommons.org/licenses/by/4.0/), which permits unrestricted use, distribution, and reproduction in any medium, provided you give appropriate credit to the original author(s) and the source, provide a link to the Creative Commons license, and indicate if changes were made. 
ways in which students can use third parties to complete work for them, with the contract spread across continents; writers may act as freelancers, working in a different country to the student and their institution. These freelance writers may make use of online auction services to advertise and organise their work and these may be in yet another country, and there may be another intermediary; an individual who receives the order from the student and then posts the work on an auction site (Newton and Lang 2016; Sivasubramaniam et al. 2016). Thus there are multiple actors in contract cheating, one or more of whom may be liable if their actions violate the law; students, their universities, the persons paying tuition fees, writers, those who employ writers, the websites which host the writers, advertising companies, those who host the advertising, and so on. Here we focus primarily on UK-registered essay-writing companies.

Across education, a student who completes an assessment to earn credit towards an award is normally required to do so on the explicit basis that the submission is their own independent work. Ideally, both students and staff are given guidance about what constitutes academic misconduct and the consequences of such misconduct (Morris 2015), in a manner that promotes a positive, constructive approach to fostering 'academic integrity' (Thomas and Scott 2016). If a student submits work that is shown to comprise, in whole or in part, material that is not their own independent work then that student will normally face a range of penalties, administered by their university, for academic misconduct. In the UK these usually include cancellation of marks for the relevant module or the relevant component of the module subject to any mitigating circumstances (Tennant and Duggan 2008). Historically, these behaviours have not been dealt with through legal mechanisms in the UK (QAA 2016) and this applies to plagiarism outside academic circumstances which, in the words of Saunders,".....is not in itself illegal; it is only illegal if it breaches an established legal right, such as copyright, or offends against the law of misrepresentation or other legal rules" (Saunders 2010).

However, a commonly used test in making legal decisions is to determine how a 'reasonable person' might view a particular behaviour. If asked to describe the purchasing of essays for submission for the purposes of gaining academic credit it seems logical to conclude that a reasonable person would conclude that such behaviour is 'fraudulent', particularly given the language associated with it (e.g. 'cheating'). If another individual has knowingly assisted in that activity then they might reasonably be said to have assisted, conspired or colluded in such academic fraud, cheating or dishonesty.

If a student has purchased written work from another individual or a company for the purpose of passing it off as his or her own work then it is clear that the student commits academic misconduct, but what of the individual or company that supplied the work in return for payment? To what extent is that individual or company (an 'assistor') complicit in such misconduct? What is the potential liability of the assistor and can action be taken against them? Are the assistors by their action inciting academic fraud? Unless the assistor is a student in the same institution an educational institution cannot normally take action against the assistor under internal disciplinary procedures. In addition, and perhaps more importantly, is there the possibility of fraudulent behaviour in the relationship between the student and the company?

Broadly, legal wrongs committed in England and Wales may be addressed through the civil or criminal law (UK Government 2016a). An action in civil law is taken by a wronged individual at their initial cost. This cost is often prohibitive and also normally 
requires the formulation of a claim recognised by the law that evidences loss or damage to the individual claimant caused by the defendant and for which a remedy is sought. Thus the ability of educational institutions (or a student for that matter) to take civil action against assistors is limited.

Action in relation to UK criminal law is normally undertaken by and at the cost of the state through the Crown Prosecution Service (CPS) but requires a criminal offence to have been committed (private prosecutions at private cost are possible but relatively rare). The Code for Crown Prosecutors sets out the basic principles to be followed by Crown Prosecutors when they make case decisions. Crown Prosecutors must be satisfied that there is enough evidence to provide a "realistic prospect of conviction" and that it is the public interest to pursue a prosecution (UK Government 2013).

A purpose of this paper is to assess the extent that a business organisation who supplies an essay or written work upon instructions from a student in return for money might be liable under the criminal law of England and Wales for an offence under the Fraud Act 2006 (The Act) (UK Government 2006). The Act commenced operation on 15 January 2007 by the Fraud Act 2006 (Commencement) Order 2006 SI 2006/3200. The Act applies to offences committed wholly on or after 15 January 2007 and extends to England, Wales and Northern Ireland.

In August 2016 the UK regulator of Higher Education, the Quality Assurance agency, considered all approaches to deal with contract cheating, a problem which they stated "poses a serious risk to the academic standards and the integrity of UK higher education" (QAA 2016). Their consideration of possible legal approaches under existing law concluded that the Fraud Act was the "nearest applicable legislation", but they did not reach a firm conclusion on its use, stating that "Case law appears to indicate a reluctance on the part of the courts to be involved in cases involving plagiarism, deeming this to be a matter for academic judgement that falls outside the competence of the court (Hines v Birkbeck College [1985] 3 All ER 15)" (QAA 2016).

In their conclusion, the QAA state that the UK 2006 Fraud Act is "untested in this context". Here we explore the detail of the Fraud Act further, and compare it to the established business practises of UK-registered essay-writing companies, with a particular focus on their Terms and Conditions.

\section{Methods}

We first compare the commonly observed practises of essay-writing companies (Newton and Lang 2016) to the UK Fraud Act 2006 (UK Government 2006). We then specifically compared the Terms and Conditions of some UK-based companies and their advertising to Sections 1-7 of the Act to determine whether or not these companies are committing an offence under these sections of the Act.

\section{Identification of companies}

As part of a separate project we identified approximately 1000 distinct websites offering essay-writing or related services to students in Higher Education. We analysed the sites to identify those which indicated that they are owned by companies listed at Companies House in the UK, meaning that they are able to run as 'legitimate' businesses and that they are subject to regulation by UK law, having been 'incorporated' under the 
Companies Act 2006 (UK Government 2016b). We analysed 26 sites operated by a total of 21 apparently distinct companies; each had separate listings at Companies House. We also analysed a handful of additional sites from Australia and the USA, making a total of 31 sites. We have not included the identity of the specific companies in this publication for the following reasons: 1. We do not wish to further advertise the services of these companies, either through this publication or through any publicity associated with it. 2. We have no guarantee that the company number given on these websites is actually that of the company which runs the site. In some cases the names are the same but in others this is not the case. 3 . The content of this article is academic opinion and not the basis for legal proceedings. We have shared, confidentially, the identities of the companies with the reviewers of this manuscript and also with the UK Quality Assurance Agency who also identified a number of UK-based companies in their recent report on essay mills (QAA 2016).

In July 2016 we accessed the websites of those companies to address a series of questions (Table 1) which would then allow us to consider the relevant sections of the Fraud Act. Questions were addressed by one author (VI) with cross checking by a second (MD). For the final question "Is the advertising potentially misleading (compared to disclaimer/ terms + conditions)?", the authors considered the advertising to be misleading if it (for example) gave the impression that work purchased from the site could be submitted as if it were a student's own work, without citing the company.

\section{Results}

Shown below are questions that we asked of the websites. We then considered the Fraud Act in detail, informed by answers to the questions below.

\section{The Fraud Act}

The Act (UK Government 2006) provides for a general offence of fraud, defined through the three ways of committing it, which are (1) by false representation, (2) by failing to disclose information and (3) by abuse of position. Each is dealt with in a separate Section of the Act. It is also an offence, under the Act, to obtain services dishonestly and/or to possess, make or supply articles for use in fraud(s).

Table 1 Questions asked of the different websites and the number/percentage of sites for which the answered was considered to be 'yes'

\begin{tabular}{|c|c|c|}
\hline Question & \# sites & $\%$ \\
\hline Is there a disclaimer of liability in respect of use? & 16 & 52 \\
\hline Are there contractual terms and conditions relating to use? & 31 & 100 \\
\hline Are customers able to specify the quality (grade) of the work)? & 20 & 65 \\
\hline Is the Intellectual Property in the work retained by the company? & 15 & 48 \\
\hline Does the work come with a 'plagiarism-free' guarantee? & 31 & 100 \\
\hline Does the site state that the products are to be used for 'research' only? & 31 & 100 \\
\hline Does the site offer 'qualified' or 'expert' writers? & 31 & 100 \\
\hline Is the advertising potentially misleading (compared to disclaimer/terms + conditions)? & 8 & 31 \\
\hline
\end{tabular}




\section{Section 3 Fraud by failing to disclose information}

We will consider Section 2 of the act ('fraud by false representation') later in this paper but at this point it is appropriate to briefly address Section 3 of the Act which makes it an offence to fail to disclose, to another, information for which there is a legal duty to disclose. For instance failing to disclose information in relation to a contract of insurance or a doctor failing to disclose to a hospital that certain patients referred by him or her for treatment are private patients, thereby avoiding a charge for the services provided. A legal duty to disclose information can arise as a result of a contract between two parties or because of the existence of a particular type of professional relationship between them; for example, a solicitor/client relationship. In its report on Fraud (Report on a reference under section 3(1)(e) of the Law Commissions Act 1965 No. $276 \mathrm{Cm} 5560$ 2002) the Law Commission made the following comments about the circumstances in which a legal duty might arise:

"7.28 ... Such a duty may derive from statute (such as the provisions governing company prospectuses), from the fact that the transaction in question is one of the utmost good faith (such as a contract of insurance), from the express or implied terms of a contract, from the custom of a particular trade or market, or from the existence of a fiduciary relationship between the parties (such as that of agent and principal).

7.29 For this purpose there is a legal duty to disclose information not only if the defendant's failure to disclose it gives the victim a cause of action for damages, but also if the law gives the victim a right to set aside any change in his or her legal position to which he or she may consent as a result of the non- disclosure. For example, a person in a fiduciary position has a duty to disclose material information when entering into a contract with his or her beneficiary, in the sense that a failure to make such disclosure will entitle the beneficiary to rescind the contract and to reclaim any property transferred under it."

Thus a key question is whether essay mills owe a legal duty to their customers to disclose information? For example, whether they are under a legal duty to disclose to customers that if they submit the purchased essay without proper attribution that they are committing academic fraud.

There is no obvious legal fiduciary relationship between the assistor and the customer (a fiduciary is someone who has undertaken to act for or on behalf of another in a particular matter in circumstances which give rise to a relationship of trust and confidence). Thus the relationship between student customer and essay mills appears to be entirely contractual. In the first instance therefore the legal duty on the part of the company is simply to comply with the terms and conditions of the contract which for the most part are set in the terms and conditions of business drafted by them. These do not routinely place a legal duty on the company to disclose information about the possible consequences of use by a student and in any event as discussed below they routinely warn against the submitting of the essay without proper attribution.

Section 3b (i) and (ii) of the Act go on to provide that an offence is only committed if by failing to disclose information the defendant "intended to make a gain for him or to cause loss to another or expose another to a risk of loss". By failing to give information that use of the essay through submission at an educational institution may lead to an academic misconduct claim a company intends to make a financial gain, i.e. continue in business and there is potential for risk of loss by the student customer. 
However essay mills are not usually under a legal duty in the first place to provide this information and in fact as discussed below the terms and conditions of business usually specifically address this point through disclaimers in relation to use of the essay (Similarly an offence under section 4 of the Act - abuse of position - is effectively negated).

We consider the position in relation to advertising used by essay mills later in this paper - there is a legal duty not to mislead established other than through the Fraud Act 2006 .

\section{Making a false representation - section 2}

This section of the Act states the following

" 2 Fraud by false representation

1) A person is in breach of this section if he-

(a) dishonestly makes a false representation, and

(b)intends, by making the representation-

(i) to make a gain for himself or another, or

(ii) to cause loss to another or to expose another to a risk of loss.

2) A representation is false if-

(a) it is untrue or misleading, and

(b)the person making it knows that it is, or might be, untrue or misleading.

3) "Representation" means any representation as to fact or law, including a representation as to the state of mind of-

(a) the person making the representation, or

(b)any other person.

4) A representation may be express or implied.

5) For the purposes of this section a representation may be regarded as made if it (or anything implying it) is submitted in any form to any system or device designed to receive, convey or respond to communications (with or without human intervention)" (UK Government 2006).

Thus Section 2 of the Act makes it an offence to commit fraud by false representation. Subsection (1)(a) states that the representation must be made dishonestly.

The current definition of dishonesty was established in $\mathrm{R} v$ Ghosh 1982. (Campbell 1984) That judgment sets a two-stage test. The first question is whether a defendant's behaviour would be regarded as dishonest by the ordinary standards of reasonable and honest people. If answered positively, the second question is whether the defendant was aware that his or her conduct was dishonest and would be regarded as dishonest by reasonable and honest people.

It seems reasonable to assume that the activities of essay writing companies would be considered 'dishonest' by ordinary standards, particularly when considering the media coverage given to their activities (Henry et al. 2014; Andrew Bomford BBC Radio 4's PM programme). However it is by no means certain that the second limb of the test would be satisfied given the rationale and justification for essay writing services usually deployed by essay mills (for example, that they offer similar services to those offered by legitimate providers, such as librarians, or they supplement study skills support that 
may be lacking in educational institutions (Newton and Lang 2016)) and the terms and conditions of business (Table 1). However, given the aforementioned publicity around their activity, a claim that they were not aware that their conduct was dishonest and would be regarded as dishonest by reasonable and honest people is subject to legitimate challenge.

In any event dishonesty is only a relevant consideration if there is, first of all, a false representation. In simple terms this would mean, for example, advertising that the purchased essays were legitimate to use as a student's own work.

Furthermore subsection (1)(b) of the Act requires for the offence to be made out that a person must make the representation with the intention of making a gain or causing loss or risk of loss to another. The gain or loss however does not actually have to take place.

Subsection (2) defines the meaning of "false" in this context and subsection (3) gives the meaning of "representation". A representation is false if it is untrue or misleading and the person making it knows that it is, or might be, untrue or misleading. Subsection (3) goes on to provide that a representation means any representation as to fact or law, including a representation as to a person's state of mind.

Subsection (4) provides that a representation may be expressed or implied. It can be stated in words or communicated by conduct. There is no limitation on the way in which the representation be expressed and therefore it could be written or spoken or posted on a website advertising essay writing services.

Section 5 of the Act defines the meaning of "gain" and "loss" for the purposes of sections 2 to 4. Under these definitions, "gain" and "loss" are limited to gain and loss in money or other property. The definitions are essentially the same as those in section 34(2)(a) of the Theft Act 1968 and section 32(2)(b) of the Theft Act (Northern Ireland) 1969. The definition of "property" which applies in this context is based on section 4(1) of the Theft Act $1968^{1}$ which includes money and all forms of property including intellectual property.

Therefore in each case of a potential offence under sections 2-4 of the Act, the defendant's conduct must be dishonest and their intention must be to make a gain or cause a loss, or the risk of a loss, to another. Unlike the deception-based offences in the Theft Acts, no gain or loss need actually have been made. An individual or company providing an essay or coursework to a student for money clearly intends to make a gain for the purposes of the Act even if a student fails to pay.

Here now we consider the specific questions addressed in Table 1 to determine whether or not false representations that were dishonest (in the in the $\mathrm{R} v$ Ghosh sense) were being made with the intention of making a gain.

\section{Terms and conditions of business}

All of the companies analysed made some sort of statement, in their terms and conditions, that essays supplied are to be used solely for 'research purposes and for assistance only' or use a variant of this form of disclaimer. Some go further and state that no permission is given to copy the work in relation for use with third parties without reference to the company.

With reference to the terms and conditions alone it cannot reasonably be argued that an individual or company is making a false representation for the purposes of the Act 
as they clearly present, in the terms and conditions, the services being supplied to student customers and the use to which essays may be put, although it has been demonstrated that every few consumers actually read online terms and conditions (Bakos et al. 2014). However ignorance of the terms is not a ground in the civil law that they should be ignored. ${ }^{2}$ A degree of protection is given to consumers under the Consumer Rights Act (UK Government 2015) which applies a 'fairness' test to all 'non-individually negotiated' contracts. These give limited protection when agreeing to unfair terms by checking a box on a website relating to terms and conditions.

Some websites also carry advertising and exhortations designed to persuade and legitimise activity, for example statements to the effect that students need not 'waste time' doing the work themselves; the recent QAA report contained numerous examples of these (QAA 2016).

The test for potential liability under section 2 of the Act is whether or not the representation is untrue or misleading and the person making it knows that it is, or might be, untrue or misleading (italics are authors emphasis). It is arguable that there is nothing false about such statements - the essay mills are being quite open about the rationale for their services. As such the representations made by essay mills are not necessarily untrue but may be misleading in that they create an impression that essays may be used legitimately, albeit contradicted by the terms and conditions accepted by the student.

There has been significant publicity over the use of purchased essays by students and it is legitimate to suggest that those offering such services are aware or ought reasonably to be aware of this use. This is evidenced in part by the terms and conditions of some of the essay mills which acknowledge that the essays supplied may be submitted in some form by students as their own work subject to a disclaimer that proper referencing as to the source is made by the student.

Therefore a reasonable and honest person might well take the view that such advertising is misleading as it might cause a student to reasonably conclude that purchasing an essay and submitting it as their own independent work is a legitimate option, but when purchasing essays students are required to acknowledge by checking a box that they have read the terms and conditions of supply which usually contradict and clarify statements made by way of advertising. Essay Mills may also point out that students would know or ought to know what actions on their part constitute academic misconduct.

The Consumer Protection from Unfair Trading Regulations 2008 are designed to protect customers from false or deceptive advertising or advertisements that leave out important information. Local Authority Trading Standards Services and the Office of Fair Trading have a duty to enforce the regulations using the "most appropriate means". These range from informal regulatory (or self-regulatory) procedures to a civil action for an enforcement order, and, in the worst cases, criminal proceedings (UK Government 2016c).

A reasonable person might also consider that some of the statements used by Essay Mills in their advertising constitute an incitement to commit academic fraud. However, as we explained previously, courts are reluctant to engage with plagiarism cases in Universities and academic fraud is not normally a criminal offence; the student falsely represents the work as his or her own but the immediate gain made by the student is 
academic credit and not money or property directly. However there is nothing in the section that requires the gain to be immediate and gain in terms of higher remuneration or salary may be made later but there is a question of whether this gain is too 'remote' - this 'remoteness' is a perceived weakness of the Fraud Act as currently drafted (e.g. see http://www.criminallawandjustice.co.uk/features/Fraudulent-Education).

In addition, although the objective test of dishonesty in $\mathrm{R} v$ Ghosh may be made out, the second aspect of the test (whether the student subjectively views the act of submission as dishonest) may be difficult to establish beyond all reasonable doubt particularly given the advertising adopted by essay writing companies. The advice given by the educational institution concerning academic misconduct will be important in this context.

\section{Making or supplying articles for use in frauds (Section 7)}

Section 7 of the Act makes it an offence to make, adapt, supply or offer to supply any article knowing that it is designed or adapted for use in the course of or in connection with fraud, or intending it to be used to commit or facilitate fraud. Section 8 extends the meaning of "article" for the purposes of sections 6 and 7 and certain other connected provisions so as to include any program or data held in electronic form. This should include an essay stored or supplied electronically. ${ }^{3}$

The specifics of the section 7 offence is that a defendant:

- makes, adapts, supplies or offers to supply any article;

- for use in the course of or in connection with fraud;

- knowing that it is designed or adapted for use in the course of or in connection with fraud (Section 7 (1) (a)) or

- intending it to be used to commit or assist in the commission of fraud (Section 7 (1) (b).

"Knowledge" in Section 7 (1) (a) is a strict requirement ${ }^{4}$ although in practice, the use to which the article can be put is likely to provide sufficient evidence of the defendant's state of mind. Furthermore as noted above the publicity over student use of supplied essays would lead to a reasonable conclusion that a supplier of an essay has relevant knowledge for the purposes of the offence.

However the manufacture of articles that are capable of being used in or in connection with fraud but have other innocent uses will not fall foul of this section unless the manufacturer intends that it should be used in a dishonest way (Section 7 (1) (b)). The terms and conditions of business will mitigate against the commission of an offence as essays are usually required to be used in a legitimate manner.

Similar barriers would apply to the section 6 offence of possession of articles for use in fraud in which it must be established that the defendant:

- had possession or control of;

- an article;

- for use in the course of or in connection with any fraud.

This section is based on Section 25 of the Theft Act 1968. It must be shown that the Defendant had the article (essay) for the purpose or with the intention that it be used 
in the course of or in connection with an offence. Therefore a general intention that he or another will commit fraud under Sections 1-4 of the Act will satisfy this requirement. In $R v$ Ellames 60 Cr App R. 7 (CA) the Court of Appeal stated:

"In our view, to establish an offence under Section 25 (1) the prosecution must prove that the Defendant was in possession of the article, and intended the article to be used in the course of or in connection with some future burglary, theft or cheat. But it is not necessary to prove that he intended it to be used in the course of or in connection with any specific burglary, theft or cheat; it is enough to prove a general intention to use it for some burglary, theft or cheat; we think that this view is supported by the use of the word "any" in Section 25 (1). Nor, in our view, is it necessary to provide that the defendant intended to use it himself; it will be enough to prove that he had it with him with the intention that it should be used by someone else."

\section{Companies Act 2006}

Section 7(2) of the Companies Act 2006 also is a further contraindication of the commission of an offence under the Fraud Act 2006 by a company providing essay writing services. This provides that a company must not be formed for an unlawful purpose. ${ }^{5}$ The decision by the Registrar of companies to incorporate a company suggests in the first instance that the business of the company is lawful. That decision is subject to judicial review ${ }^{6}$ and a certificate of incorporation is not conclusive evidence that all the company's business is legal. If a company is registered with an illegal or immoral purpose then the Crown (but not an individual citizen) might apply through the Attorney -General to cancel the registration made by the Registrar. ${ }^{7}$

Although companies that offer essay writing services may have been established prior to the coming into force of the Companies Act 2006 the requirement of incorporation for lawful purposes only is an established principle applying in respect of the incorporation of companies prior to this date. Thus at the time of incorporation the Registrar must have been satisfied that the essay writing companies were formed for a lawful purpose.

The conclusion drawn by the authors therefore is that the terms and conditions of business accepted by students (notwithstanding the protections given by the civil law) effectively negate or make it difficult to establish the elements of a criminal offence under the Fraud Act 2006.

\section{Discussion}

In their recent report "Plagiarism in Higher Education", the QAA recommend investigating legislative approaches to tackle contract cheating in the UK and identified the UK 2006 Fraud Act as the most obvious means to pursue action (QAA 2016). Here we conclude that the Act, as it currently stands, is unlikely to provide a successful platform for addressing contract cheating through legal means - particularly if the aim is to prosecute the companies who offer these services.

This is despite there being some obvious contradictions within the websites - all of the sites contain some form of statement that their products are 'to be used for research purposes only' yet all also offer some form of 'plagiarism-free guarantee'. It is difficult to conceive of a situation where a plagiarism-free guarantee would be needed 
for a custom-written essay, unless it was to be used for submitting as the customer (student's) own work. The companies may need to protect themselves from copyright violation, but this is distinct from plagiarism and would be a matter for the companies rather than something advertised to their customers.

It might be considered that the behaviours of students using these services could fit UK legal definitions of fraud although, as explained earlier, the courts have traditionally been reluctant to intervene in academic issues. There are also a number of potentially damaging consequences to the criminalisation of student behaviour in this way, such as the undermining of trust between students and their universities and the role of university staff in such a situation; which would turn academic misconduct into a legal situation. At the very least, this would seem likely to deter action.

There is a general presumption that some form of intention or knowledge (mens rea) is necessary for the commission of a criminal offence because of the impact of criminal penalties (including loss of liberty). However, some offences are specifically enacted as offences of 'strict liability', meaning, basically, that there is no requirement to demonstrate 'intent', fault' or 'negligence,' although these may then be considered when determining a penalty. Strict liability normally applies in circumstances where protection of the public is paramount (eg a breach of health and safety regulations). The authors propose that a new strict liability criminal offence is enacted specifically addressing the supply of academic essays to avoid the need for a prosecutor to establish intention or knowledge as a prerequisite to criminal liability. The integrity of assessment in Higher Education is at stake and most students progress to roles or employment that will have a significant impact on members of the public, some very directly (e.g. nurses, doctors, lawyers)

An example of an offence of strict liability might be (adapted from existing US Legislation (Newton and Lang 2016)):

"No person shall, for financial consideration, or the promise of financial consideration, prepare, offer to prepare, cause to be prepared, sell or offer or advertise for sale to any person any written material which may be submitted as a coursework, dissertation, essay, project report or any other form of assignment (written or otherwise) by a student in a university, college, academy, school or other educational institution to such institution or to a course, seminar or degree program held by such institution"

Offences of strict liability promote high standards of care, provide a strong deterrent, make enforcement easier and usually operate in relation to businesses in which the penalty is a fine so that individual liberty is not at stake. However the penalty should be substantial to avoid companies simply viewing a fine as an expense of the business or a nominal tax on illegal enterprise. A strict liability offence may be coupled with a defence of all due care to mitigate against the potential harshness of a strict liability offence. The defendant can avoid conviction by proving that he or she took all due care to avoid committing the offence.

Other jurisdictions have enacted specific offences addressing the mischief of essay writing services. Most require some form of intention or knowledge on the part of the offender and this leads to difficulty in establishing liability based on available evidence. 
However this could easily be incorporated into the proposal above by adding a caveat, as shown below with modifications in italics

"No person shall, for financial consideration, or the promise of financial consideration, prepare, offer to prepare, cause to be prepared, sell or offer or advertise for sale to any person any written material which the seller knows, is informed or has reason to believe is intended for submission as a coursework, dissertation, essay, project report or any other form of assignment (written or otherwise) by a student in a University, college, academy, school or other educational institution to such institution or to a course, seminar or degree program held by such institution"

Internationally there have been efforts to pursue contract cheating through legal means and these were described in detail in a recent chapter of the Handbook of Academic Integrity (Newton and Lang 2016). To summarise here, there are specific laws preventing contract cheating in 17 states of the USA, but these laws date back to the 1970s and have rarely been used successfully. More recently New Zealand developed a law which made it illegal to advertise or to provide 'third party assistance to cheat' and this includes circumstances beyond essay writing, such as sitting an exam on behalf of another. Again, this law does not appear to have been commonly used. Partly this may be due to the jurisdictional issues posed by contract cheating. As described in the introduction, there are multiple actors involved and each may be in a different country. Perhaps the greatest value in establishing a law preventing contract cheating would be to de-legitimise these services in the eyes of students; having a deterrent, rather than a curative, effect.

Despite our conclusion that the current activities of UK-based essay writing companies do not appear to violate the terms of the 2006 Fraud Act, we have identified other possible legal approaches to addressing contract cheating via a legal means. The first is in the apparent discrepancy between the terms and conditions used by the companies, which frequently urges caution in the use of purchased assignments for misconduct, and their advertising which can actively encourage it. In the UK this is, potentially, a violation of the "Consumer Protection from Unfair Trading Regulations 2008" which are designed to protect customers from false or deceptive advertising or advertisements that leave out important information. Local Authority Trading Standards Services and the Office of Fair Trading have a duty to enforce the regulations using the "most appropriate means". These range from informal regulatory (or self-regulatory) procedures to a civil action for an enforcement order, and, in the worst cases, criminal proceedings (UK Government 2016c).

Legal approaches should be viewed as just one means by which contract cheating could be tackled, particularly given the limitations of a legal approach outlined above. Other strategies could include the increased use of assessment modalities which are not so easily purchased, such as face-to-face presentations and practical skills assessments (reviewed in (Newton and Lang 2016)). Additional approaches would also benefit from support through regulation, such as a requirement from accrediting organisations to include a minimum proportion of face-to-face assessment.

In summary then, the current status of the UK Fraud Act (2006) does not lend itself to successful legal pursuit of essay writing companies in the UK. However this could be addressed with a modification to the Act. The principles identified could be adopted in other countries. 


\section{Endnotes}

${ }^{1}$ Read with section 34(1) of that Act and section 4(1) of the Theft Act (Northern Ireland) 1969 (read with section 32(1) of that Act).

${ }^{2}$ L'Estrange v F. Groucob Ltd [1934] 2 KB 394

${ }^{3} \mathrm{R}$ v Akpom [2013] EWCA Crim 2662 The defendant worked in a registry office. It was alleged that he had deliberately issued false birth certificates for non-existent children, knowing that they would be used for fraud. Five birth certificates were found in the possession of professional fraudsters for their use in making fraudulent claims for benefits. A certificate was held to be an 'article'

${ }^{4} \mathrm{R}$ v Montila [2004] UKHL 50

${ }^{5} \mathrm{R}$ v Registrar of Joint Stick Companies, ex parte More [1931] 2 KB 197

${ }^{6} \mathrm{R}$ v Registrar of companies, ex parte A-G [1991] BCLC 476 - attempted registration of a company to carry on the business of prostitution

${ }^{7}$ Bowman v Secular Society [1917] AC 406

\section{Acknowledgements}

The authors would like to thank Dr Patrick Bishop of the College of Law and Criminology for reviewing the manuscript prior to submission.

\section{Authors' contributions}

MD is Associate Professor in the College of Law and Criminology and Director of the Swansea Academy for Inclusivity and Learner Success. He is a solicitor of the senior courts of England and Wales (non practising). He analysed the content of the websites against the UK 2006 Fraud Act and wrote the manuscript with PN. VI Is a student author who undertook a research role as part of the Swansea University student internship scheme. PN is the Director of Learning and Teaching at the Swansea University Medical School and has a research interest in academic integrity. He identified the sites and their common practises. He also wrote the manuscript with MD. All authors read and approved the final manuscript.

\section{Competing interests}

The authors declare that they have no competing interests.

\section{Author details}

${ }^{1}$ College of Law and Criminology, Swansea University, Swansea SA2 8PP, UK. 'Swansea University Medical School, Swansea University, Swansea SA2 8PP, UK.

Received: 8 November 2016 Accepted: 18 January 2017

Published online: 25 January 2017

\section{References}

Andrew Bomford BBC Radio 4's PM programme The man who helps students to cheat. In: BBC News. http://www.bbc. co.uk/news/magazine-36276324. Accessed 1 June 2016

Bakos Y, Marotta-Wurgler F, Trossen DR (2014) Does anyone read the fine print? Consumer attention to standard form contracts. Social Science Research Network, Rochester, NY

Campbell K (1984) The Test of Dishonesty in R. v. Ghosh. Camb Law J 43:349-360. doi:10.1017/S0008197300112632

Henry R, Flyn C, Glass K (2014) $£ 630$ and I'll put you on the way to a first'

Lancaster T, Clarke R (2016) Contract cheating: the outsourcing of assessed student work. In: Bretag T (ed) Handbook of academic integrity. Springer, Singapore, pp 639-654

Morris EJ (2015) Academic integrity: a teaching and learning approach. In: Bretag TA (ed) Handbook of academic integrity. Springer, Singapore, pp 1-14

Newton P (2015) Academic integrity: a quantitative study of confidence and understanding in students at the start of their higher education. Assess Eval High Educ 0:1-16. doi:10.1080/02602938.2015.1024199

Newton PM, Lang C (2016) Custom essay writers, freelancers, and other paid third parties. In: Bretag T (ed) Handbook of academic integrity. Springer, Singapore, pp 249-271

QAA (2016) Plagiarism in Higher Education - Custom essay writing services: an exploration and next steps for the UK higher education sector

Saunders J (2010) Plagiarism and the law. Learn Publ 23:279-292. doi:10.1087/20100402

Sivasubramaniam S, Kostelidou K, Ramachandran S (2016) A close encounter with ghost-writers: an initial exploration study on background, strategies and attitudes of independent essay providers. Int J Educ Integr. doi:10.1007/ s40979-016-0007-9

Tennant P, Duggan F (2008) Academic Misconduct Benchmarking Research (AMBeR) Project Part II Executive Summary

Thomas J, Scott J (2016) UK perspectives of academic integrity. In: Bretag T (ed) Handbook of academic integrity. Springer, Singapore, pp 39-53

UK Government E (2006) Fraud Act 2006. http://www.legislation.gov.uk/ukpga/2006/35/contents. Accessed 10 Sept 2016 
UK Government (2013) The CPS : The Code for Crown Prosecutors

UK Government (2015) Consumer Rights Act 2015

UK Government (2016a) Your rights and the law - GOV.UK.

UK Government (2016b) Incorporation and names - Publications - GOV.UK.

UK Government (2016c) Marketing and advertising: the law - GOV.UK

Wallace MJ, Newton PM (2014) Turnaround time and market capacity in contract cheating. Educ Stud 40:233-236. doi:10. 1080/03055698.2014.889597

\section{Submit your manuscript to a SpringerOpen ${ }^{\circ}$ journal and benefit from:}

$\checkmark$ Convenient online submission

- Rigorous peer review

- Immediate publication on acceptance

- Open access: articles freely available online

- High visibility within the field

- Retaining the copyright to your article

Submit your next manuscript at $\boldsymbol{\nabla}$ springeropen.com 